\title{
CORPORATE GOVERNANCE MECHANISMS IN THEORY AND PRACTICE OF HOUSING COOPERATIVES
}

\author{
Aneta Brzeska \\ University of Szczecin, Szczecin, Poland \\ e-mail: aneta.brzeska@usz.edu.pl \\ ORCID: 0000-0001-9389-2762 \\ Anna Mazurczak-Mąka \\ Cracow University of Economics, Cracow, Poland \\ e-mail: mazurcza@uek.krakow.pl \\ ORCID: 0000-0003-1723-5167 \\ (C) 2019 Aneta Brzeska, Anna Mazurczak-Mąka \\ This is an open access article distributed under the Creative Commons Attribution-NonCommercial-NoDerivs license \\ (http://creativecommons.org/licenses/by-nc-nd/3.0/) \\ DOI: $10.15611 / \mathrm{ms} .2019 .4 .02$ \\ JEL Classification: G3, R3
}

\begin{abstract}
The research goal is to present the results of research on corporate governance mechanisms used by supervisory boards when assessing the management of the activities of Polish housing cooperatives. To achieve this goal, the essence of corporate governance and its mechanisms in relation to housing cooperatives were analyzed, followed by empirical research whose respondents were members of supervisory board. The research object is a housing cooperative operating in Poland. Achievement of the objectives of the article was possible due to an in-depth study of domestic and foreign literature related to the topic of the work, as well as the application of the survey method.
\end{abstract}

Keywords: housing cooperatives; oversight mechanisms, corporate governance, supervisory boards, audit.

\section{Introduction}

In Polish housing cooperatives, the cooperative members do not directly perform managerial functions, they only delegate them to persons appointed by authorized bodies of the cooperative for this purpose. As a result of using appropriate mechanisms and resources, their task is to ensure that the needs of members of housing cooperatives are met.

Thus an analysis of the behaviour of members and the management of the organization shows that decisions can be determined by the need to verify the activities of a housing cooperative, and thus relates to the issues of the agency theory ${ }^{1}$. Therefore it is important to clarify the relationship between the principal (members of a housing cooperative) and the agent (member of the managing bodies of a housing cooperative) hired to manage the property of the principal.

In agency theory exists a situation where the principal is unable to verify the correctness of the agent's activities, since this monitoring is costly and difficult to perform [Eisenhardt 1989, pp. 57-74]. This problem relates to the concept of corporate governance. Effective corporate governance ensures the better functioning of the housing cooperative. As noted by Gad, currently "there are no universal solutions for corporate governance tailored to all

\footnotetext{
${ }^{1}$ According to the definition of M.C. Jensen and W.H. Meckling, it is "an agreement whereby one or more persons (principal), with the involvement of another person (agent), commission the service on their behalf by delegating powers and means to make decisions". See: [Jensen, Meckling 1976, p. 308].
} 
economic structures and all phases of the business cycle" [2012, p. 777].

The problem of the assessment and analysis of corporate governance mechanisms is often raised in literature. Walczak diagnosed and explained the key problems related to the activities of supervisory bodies and dealt with the weakness of owner supervision on the part of members of cooperatives ${ }^{2}$. The conducted analysis of literature, however, indicates the existence of a research gap regarding the lack of research related to the assessment of the functioning of corporate governance of housing cooperatives in the context of the assessment by members of the supervisory board. It should be emphasized that the supervisory board has a crucial role in supervision, as it performs both the role of an internal (referring to positioning in the structure of a housing cooperative) and an independent guardian of the interests of a housing cooperative.

Identifying the gap was the basis for determining the main goal of the paper, which is to present the results of research on mechanisms of corporate governance used by supervisory boards for the assessment of the management activities in regard to Polish housing cooperatives. To achieve this goal, the essence of corporate governance and its mechanisms were analyzed in relation to housing cooperatives. Then, empirical research was carried out in which the respondents were members of the supervisory boards of housing cooperatives. Achievement of the objectives of the article was possible after conducting an in-depth study of domestic and foreign literature analysis related to the topic of the work, and by using the survey method.

\section{The issue of corporate governance}

The issue of corporate governance is a common research problem in management literature, although despite the efforts of researchers and practitioners, no comprehensive theory or model defining the essence of corporate governance has been created. It is an ambiguous concept derived from finance, law, sociology, organization and management [Gabrusewicz 2010, p. 63]. In Poland the term 'corporate governance' is used interchangeably with terms such as 'corporate overseeing', 'ownership supervision', and 'ownership governance' [Dobija, Koładkiewicz 2010, p. 15].

Among many other definitions of corporate governance (corporate governance, governance and corporate oversight), the one contained in the preamble to the OCED Corporate Governance Principles in particular deserves attention. It clarifies corporate governance [Jeżak 2013, p. 22] as “(...) a network of relations between the management staff of companies and their supervisory bodies, shareholders and other interest groups interested in the functioning of the company. Corporate governance also includes a structure through which the company's objectives, means of achieving these objectives and measures to track the company's results are determined" [Ministerstwo Skarbu Państwa 2004, p. 11].

According to Jeżak, the modern understanding of the term corporate governance, concerns the way of enforcing the set of property rights (primarily relations between shareholders, their formal proxies and the company's management board), extended by the right to control the company by other stakeholders, taking into account the state, capital market, trade unions, employers' associations, etc., and extended to include corporate social responsibility regulations, including increased ethical standards and specific behavioural patterns of investors, managers, bank employees and audit units, popularized in the form of codes of good corporate practice [Jeżak 2013, p. 24]. Thus, the term means a system that aims to balance the expectations of members of the organization and their egoistic behaviour [Dobija, Koładkiewicz 2010, p. 15].

Corporate governance as a system includes mandatory legal regulations, which include the Commercial Companies Code, banking law, the accounting act and the Act on statutory auditors, as well as voluntary recommendations the application of which is expected by users of financial information in regard to commercial entities of public trust, i.e. 'comply or explain' principles [Gabrusewicz 2010, p. 63]. As an element of the corporate governance system in relation to housing cooperatives, Cooperative Law should also be indicated.

In turn, the new dimension of corporate governance, i.e. socially responsible or the culture of increased responsibility is combined with the demand for increasing corporate transparency. According to many authors, this so-called 'spirit of transparency', along with a culture of greater responsibility, is becoming a fundamental condition for the reconstruction of public trust. First of all, this applies to complete financial statements published as reliable in every aspect and for which access should have been facilitated [Jeżak 2013, p. 24].

Due to the different interpretation of the term 'corporate governance', the authors adopted the version in accordance with Jeżak's work that in Polish, emphasizes the broader, social and systemic context of entities' operations, which obligatorily

\footnotetext{
${ }^{2}$ See: [Walczak 2011A; 2011B; 2012; 2013A; 2013B; 2014].
} 
takes into account their conditions and expectations that stem from macroeconomic or social environment. It should be emphasized that a modern corporation is also a social and not only an economic institution, as its goal is to maximize value for both investors and other interest groups [Jeżak 2013, pp. 23-26].

Corporate governance is also the supervision and control exercised by statutory bodies designated for this purpose, other groups interested in the entity or having an interest in its functioning. These are rules, principles, mechanisms, institutions controlling various aspects of unit management, research tools and control over management in the unit [Zalega 2003, p. 15].

The constituent part of the concept of corporate governance is limiting conflicts arising between managers and owners of capital in units, as well as the costs generated by these conflicts [Gabrusewicz 2010, p. 63].

The essence of corporate governance is to guarantee a pro-development balance between the interests of all entities involved in the functioning of the corporation. This statement should be broadened and it should be added that it is a system through which these corporations are managed and controlled, which consequently minimizes the transaction costs of business entities. This broad concept is also understood as a collection of relationships in a corporation [Masny 2002, p. 1] between providers of capital, services, a product, human resources, and clients. Corporate governance also applies to auditing, accounting policies, and shareholder activities, and may include all rights that ensure accountability to shareholders and the general public [Gabrusewicz 2010, p. 72].

A thriving corporate governance system should properly stimulate the entity's governing bodies and the entity's management staff to achieve the objectives of the entity and its associates, as well as effectively facilitate the tracking of results, which promotes the proper use of resources by the entity [Gabrusewicz 2010, p. 66].

A modern corporate governance system should be characterized by efficient and effective market control and supervision mechanisms, domination of institutional investors [Dembiński 2003] and striving to improve internal control mechanisms over broadly understood business unit management [Gabrusewicz 2010, p. 72].

In relation to the essence of corporate governance, maintaining its balance is not an easy task, because each change in the expectations or behaviour of corporation members can contribute to the disturbance of proportions between the legal regulations and the social norms in force in a given society, as well as market forces. This means that a single effective corporate governance system does not exist, but the process of maintaining balance in this system [Dobija, Koładkiewicz 2010, p. 8] depends on specific factors such as principles, methods and procedures that then determine the success or failure to meet expectations related to the oversight function, i.e. the oversight team's contribution to the long-term success of the supervised entity. All the factors shaping effective corporate governance can be systematized by dividing them into three groups: systemic factors, efficiency factors at the oversight body level and efficiency factors at the level of the members of the oversight body ${ }^{3}$. Regarding the above, shaping an effective corporate governance system has always been one of the most important tasks that participants of each corporation have to face [Dobija, Koładkiewicz 2010, p. 8].

Corporate governance makes an important contribution to the development of science, economics and finance, because it helps in better understanding the mechanism of functioning of entities, in particular issues of authority systems, ownership or strategic decision-making processes in these entities [Jeżak 2013, p. 35]. The essence of the corporate governance should be "to ensure an effective and substantial control of the activities of management boards while seeking to ensure an efficient system of organizational management in accordance with the applicable laws" [Walczak 2013, p. 59].

\section{Corporate governance mechanisms in the context of housing cooperatives}

The issues associated with corporate governance in the literature are usually concentrated on the functioning of companies, but according to the authors they can be also applied to housing cooperatives. "The mechanisms of properly understood governance in housing cooperatives should primarily focus on ensuring that the rights and interests of all residents are respected", as the residents are the key stakeholders who are paying monthly rent and are financing the operations undertaken by those organizations [Walczak 2013, p. 59].

Housing cooperatives, as independent business entities, are co-creators of the market economy system [Walczak 2011A, p. 45]. They are distinguished by their character from other business entities because they are a combination of an association and an enterprise [Konieczna 2015, p. 7]. The bodies of a housing cooperative include in principle the general

\footnotetext{
${ }^{3}$ See: [Jeżak 2010, p. 197].
} 
Table 1. The scope of activities of the bodies of a housing cooperative

\begin{tabular}{|c|c|c|}
\hline General Meeting & Supervisory Board & Management Board \\
\hline $\begin{array}{l}\text { Choosing delegates for the congress of the association } \\
\text { in which the cooperative is affiliated. }\end{array}$ & $\begin{array}{l}\text { Control and oversight over the cooperative's activities by } \\
\text { examining periodic reports and financial statements; } \\
\text { periodic assessments of the cooperative's performance of } \\
\text { entrusted economic tasks, in particular compliance of the } \\
\text { cooperative with the rights of its members; conducting } \\
\text { reviews of the way the management board handles } \\
\text { applications of members and bodies of the cooperative. }\end{array}$ & $\begin{array}{l}\text { Managing } \\
\text { the day-to-day } \\
\text { activities } \\
\text { of the cooperative. }\end{array}$ \\
\hline $\begin{array}{l}\text { Adopting directions for the development of economic, } \\
\text { cultural and social activities. }\end{array}$ & $\begin{array}{l}\text { Adoption of cultural and social activity programs and } \\
\text { economic plans. }\end{array}$ & $\begin{array}{l}\text { Representing the } \\
\text { cooperative in } \\
\text { external relations. }\end{array}$ \\
\hline $\begin{array}{l}\text { Considering the reports of the supervisory board, } \\
\text { approving annual reports and financial statements, } \\
\text { adopting resolutions regarding motions submitted by } \\
\text { cooperative members, the management board or the } \\
\text { supervisory board in these matters and granting } \\
\text { discharge to the management board members. }\end{array}$ & $\begin{array}{l}\text { Submission of reports containing in particular the result of } \\
\text { the audit and assessment of the financial statements to the } \\
\text { general meeting. }\end{array}$ & \multirow[t]{4}{*}{$\begin{array}{l}\text { Undertaking } \\
\text { decisions that are } \\
\text { not reserved to } \\
\text { other bodies in the } \\
\text { law or in the statute } \\
\text { of the cooperative. }\end{array}$} \\
\hline $\begin{array}{l}\text { Considering motions resulting from the submitted } \\
\text { protocol of lustration activities of the cooperative's } \\
\text { activities and adopting resolutions in this area and } \\
\text { deciding appeals against resolutions of the supervisory } \\
\text { board in internal proceedings. }\end{array}$ & $\begin{array}{l}\text { Deciding complaints regarding the activities of the } \\
\text { management board. }\end{array}$ & \\
\hline $\begin{array}{l}\text { Adopting resolutions on: } \\
\text { - sale of real estate, sale of a plant or other separate } \\
\text { organizational unit, } \\
\text { - distribution of the balance sheet surplus (general } \\
\text { income) or method of covering losses, } \\
\text { - mergers, liquidation or division of cooperatives, } \\
\text { - joining other business entities and withdrawing from } \\
\text { them, } \\
\text { changes in the statute, regarding joining or } \\
\text { withdrawal of a cooperative from a union and } \\
\text { authorizing the management board to take action in } \\
\text { this matter. }\end{array}$ & $\begin{array}{l}\text { Adopting resolutions on: } \\
\text { - encumbrance and purchase of real estate; acquisition } \\
\text { of an organised workplace, acquisition of another } \\
\text { organizational entity, } \\
\text { - legal transactions between the cooperative and } \\
\text { a member of the management board or carried out by } \\
\text { the cooperative in the interest of a member of the } \\
\text { management board, or representing the cooperative in } \\
\text { these activities (two representatives of the supervisory } \\
\text { board authorized by the board are sufficient to represent } \\
\text { the cooperative), } \\
\text { - joining social organizations and withdrawing from } \\
\text { them. }\end{array}$ & \\
\hline $\begin{array}{l}\text { Determining the highest limit of obligations that } \\
\text { a cooperative can undertake. Adopting amendments to } \\
\text { the statute. }\end{array}$ & Approving the organizational structure of the cooperative. & \\
\hline
\end{tabular}

Source: own study on the basis of [Blaszke, Śpiewak-Szyjka 2015, pp. 143-145, Cooperative Law].

meeting, the supervisory board and the management board ${ }^{4}$. Each organ has its own exclusive properties (see Table 1.1). The issue of control and oversight over the activities of a housing cooperative falls into the scope of its supervisory board.

Corporate governance in entities that can be considered corporations also relates to auditing, accounting principles, shareholder activities and may include all rights ensuring liability towards shareholders (in the broad sense) and the general public [Gabrusewicz 2010, p. 72].

An important problem is the effective functioning of corporate governance in the context of the activities of housing cooperatives, in which the institutions of the internal and external mechanism of oversight can be recognized. Under the internal corporate governance mechanism, it is possible to recognize the so-called ownership supervision, which is carried out with a leading role of the supervisory board, to which in which in principle only members of the housing cooperative can be appointed and, whose powers and tasks predominantly include the economic and non-economic oversight of the activities of the housing cooperative.

In the practical functioning of supervisory boards of a housing cooperative, there is often a problem in

\footnotetext{
${ }^{4}$ This principle of tripartite division of cooperative bodies is required for the legally effective functioning of each cooperative. This tripartite division of the cooperative's statutory bodies is specific to corporate-type entities. See: [Dąbrowski 2013, p. 55].
} 
the implementation of proper supervision, because members of supervisory boards may not have a sufficient level of economic and legal knowledge ${ }^{5}$ or may perceive the interests of members in the perspective of their own interests. It also happens that persons who are recognized, or who are more active than other members in the course of the general meeting, are appointed as members of the supervisory board. In such situations, the substantive level of their activity is not assessed by the other members, only the mere fact of speaking out, often in matters concerning themselves. It may also be a wrong decision to choose a control body under external corporate governance mechanisms, which is made by the supervisory board ${ }^{6}$.

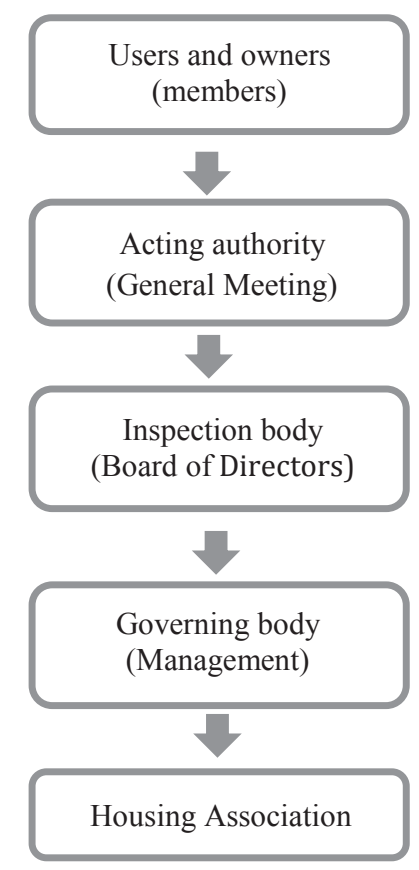

Fig. 1. Corporate governance scheme in housing cooperatives Source: own study.

The members of a housing cooperative may be in a way the second body of the internal corporate governance mechanism, as the law grants the cooperative members the right to participate extensively and effectively in the oversight processes ${ }^{7}$. On the basis of this legal regulation, housing cooperatives can be subject to effective membership control - this ensures the building of high standards of democratic internal oversight and supervision mechanisms [Walczak 2014, pp. 147-148].
Members of a housing cooperative, however, do not necessarily express a willingness to actively participate in the life of the cooperative, and may prefer to be passive observers. As a result, ownership supervision on the part of cooperatives is defective [Walczak 2014, p. 136]. The recommended solution is to use external mechanisms of governance, adequate to the specifics of the housing cooperative, i.e. financial audit and inspection, which could partially fill this gap [Dworniak, Pietrzak 2014, p. 64]. Agency theory applies to cooperative (or corporate) governance.

Constructing a supervision mechanism to solve the agent's problem is a major challenge in agency theory. As noted by $\mathrm{Gad}$ in the literature on the subject, first of all two solutions are emphasized which are a matter of selecting the principal (Gad, 2011 , pp. 22-23), i.e. contracts based on results and monitoring of the agent's actions. The first solution correlates the interests of the agent and principal, who can formulate the economic conditions of the contract in such a way that there is a correlation between the agent's performance and the stimulus system. This variant applies to "output-oriented control".

The monitoring is intended to improve the efficiency of the information system, to supervise the agent by the client to eliminate the phenomenon of information asymmetry. This means that it is solved by "controlling the inputs".

Theoretically, in a housing cooperative the effectiveness of corporate governance can be strengthened by translating it into a cooperative management method that will increase the level of involvement and attendance as well as the active participation in the general meetings by cooperative members. However, it is difficult to require members of a housing cooperative to engage in its affairs and control in a situation in a situation where they only want to occupy an apartment in the housing cooperative's resources and to delegate the oversight the operations of the housing cooperative to the members appointed to the supervisory board. Thus in this situation the role of the supervisory board, which is appointed to control the activities of the management board of a housing cooperative, significantly increases. The cooperative activities should be transparent to all stakeholders [Szczypiór 2016, p. 42].

\footnotetext{
${ }_{5}^{5}$ The legislator did not specify the qualification requirements regarding the knowledge required to become a member of the supervisory board.

${ }^{6}$ For more on the mistakes made by Supervisory Boards, see: [Walczak 2013A, pp. 58-81].

7 See art. $8^{1}$, paragraph 1 of the Act on housing cooperatives, more widely commented on later in this work.

${ }^{8}$ For agency theory regarding the relationship between the manager and owner of capital, see more [Gad 2011, pp. 22-23].
} 


\section{The supervisory board as a part of the corporate governance in housing cooperatives}

In the realities of overseeing housing cooperatives a need arises to diagnose the currently used corporate governance mechanisms by supervisory boards in Polish housing cooperatives. This kind of studies have not been conducted so far.

An important element of the study was the evaluation and assessment of the manner in which members of the supervisory board verify the efficiency and effectiveness of the structures and processes used. To achieve the main objective of the article, surveys were conducted among the members of the supervisory board of housing cooperatives. In the study, the authors used structured questions using a disjunctive response format (the respondent was asked to indicate one of many possible answers). A large part of the study concerned questions about the use and usefulness of corporate governance mechanisms' products in housing cooperatives. The survey was launched in the fourth quarter of 2018 via the Internet (CAWI method), using the Webankieta program (a program for creating online surveys).

The link assigned to it was sent to a randomly selected sample with a request to complete the survey to the indicated groups of entities. Surveys addressed to members of the supervisory boards of Polish housing cooperatives were sent to nearly 150 entities from the housing cooperative contact database, prepared for the needs of the study, operating in various parts of Poland 9 . A total of 19 surveys were collected in electronic form ${ }^{10}$. It should be noted that the selection of the sample was deliberate and random (the technique of individual sampling was chosen). On the other hand, the aggregate and selected results obtained will be presented as a percentage of the responses given.

The respondents answering the first question regarding the indication of which mechanism of oversight of the activities of a housing cooperative most closely meets the expectations of the respondents, they equally indicated that such expectations are met by both the inspection and the financial audit. However, there were also respondents indicating that the internal survey meets the expectations of $6 \%$ of all respondents (see Figure 2).

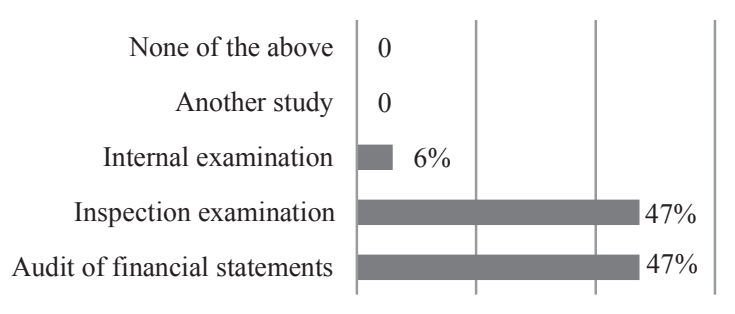

Fig. 2. The overseeing mechanism which meets the supervisory board members' expectations to the greatest extent

Source: own study.

At the same time, the respondents indicated that they most often analyze the inspection protocol, and $5 \%$ of them indicated that other internal documentation is analyzed by them (see Figure 3).

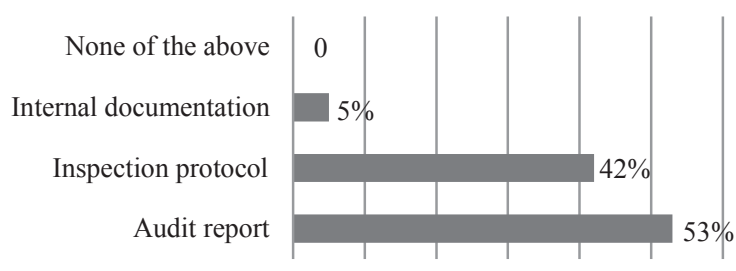

Fig. 3. The product of the corporate governance mechanism most often analyzed by members of the supervisory board of a housing cooperative

Source: own study.

Another question confirmed the respondents' opinion that they obtained knowledge of the housing cooperative's activities from the inspection protocol. The respondents were also given the opportunity to indicate other corporate governance mechanisms used to acquire knowledge about the activities of a housing cooperative, among which $5 \%$ of respondents mentioned that they obtained information from: members of the housing cooperative's management board, from the financial statements, and from reports prepared by employees for the supervisory board. Therefore, having acquired knowledge about the functioning of housing cooperatives, the survey participants were asked whether their information needs in this respect were met. It can be said that the responses were divided between "rather yes" and "rather not", which may indicate existing information needs that should be diagnosed (see Figure 4). Findings from interviews in the research conducted by Kyaitha and Nzioki (2017) revealed

\footnotetext{
${ }^{9}$ In order to find contacts to the database, an internet search engine was used and in the order of appearing responses in the search engine a housing cooperative was selected to the database

10 The low rate of return of the surveys, amounting to $12.67 \%$, does not allow for the generalization of research results for the whole community. However, the authors see in the research results an important signal regarding the functioning of corporate governance mechanisms in Polish housing cooperatives.
} 
that the question of transparency in the activities of the housing cooperatives play a significant role. Full disclosure of reliable of financial and non-financial information is important not only for corporations, but is also appropriate for housing cooperatives and can help their shareholders to make informed decisions.

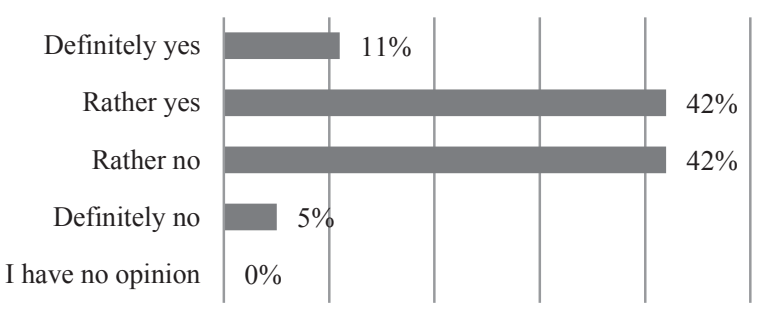

Fig. 4. Level of satisfaction of information needs on the functioning of a housing cooperative

Source: own study.

The respondents see the positive impact of carrying out two forms of housing cooperative auditing because it results in a significant increase in the level of trust in relation to the reliability of information generated by the management board of the housing cooperative.

The results of the research help to better understand how cooperative overseeing mechanisms work in a cooperative. This is fairly important information in the context of the significance and role they are to play as a carrier of financial and non-financial information. It seems that in the examined housing cooperatives, members of the supervisory board correctly assess the implemented mechanisms of overseeing.

\section{Conclusion}

All management boards of housing cooperatives are supported and legitimized by supervisory boards [Walczak 2014, p. 148]. Members of the supervisory board decide on the efficiency of corporate governance through personal commitment, and their attitude affects the organization which is the housing cooperative itself. The theoretical considerations and empirical research carried out earlier allowed the assessment of the corporate governance mechanisms applied. This conclusion was supported by the results of the current diagnosis. The approach adopted by the authors made it possible to get to know the opinions of the respondents whose work is directly related to the activities of housing cooperatives. It is therefore necessary to promote the essence of corporate governance in the environment of housing cooperatives. Housing cooperatives will function efficiently, but they must adopt a mechanism that allows the evaluation and review of the managers of a housing cooperative.
It can therefore be concluded that in order to strengthen the effectiveness of corporate governance mechanisms, the efficiency and appropriateness of their use, as well as strict compliance with the law, are important. This means that the corporate governance mechanisms should take over the key foundation which is responsibility - meaning the obligation of a housing cooperative body to provide an account before its members. At the end of the day, the corporate governance mechanism is as strong as its weakest link in the chain constituted by: authors of the reports, supervisory boards and external authorities. The authors emphasize that the selected and the presented research results do not give grounds for confirmation in other housing cooperatives, however, they are a part of a broader discussion and provide motives for further research in the relevant area.

\section{Bibliography}

Blaszke M., Śpiewak-Szyjka M. (2015), Satysfakcja członków spótdzielni i innych osób korzystajacych z zasobów mieszkaniowych spółdzielni, [in:] Spółdzielnie mieszkaniowe. Dylematy funkcjonowania i rozwoju, Skotarczak T. (red.), Wydawnictwo C.H. Beck, Warszawa.

Dąbrowski T. (2013), Zarząd w strukturze organów spótdzielni, Rocznik Samorządowy, t. 2.

Dembiński A. (2003), Zamknięty model nadzoru korporacyjnego - czy jesteśmy na niego skazani?, Nasz Rynek Kapitałowy, nr 1 .

Dobija D., Koładkiewicz I. (2010), Ład korporacyjny, Wolters Kluwer Polska, Warszawa.

Dworniak J., Pietrzak M. (2014), Spółdzielczość mleczarska specyfika ekonomiczna i rola rewizji finansowej w nadzorze korporacyjnym, Studia Prawno-Ekonomiczne, t. XCI/2.

Eisenhardt K.M. (1989), Agency theory: an assessment and review, The Academy of Management Review, vol. 14, no. 1, pp. 57-74.

Gabrusewicz T. (2010), Rachunkowość odpowiedzialności społecznej w kształtowaniu zasad nadzoru korporacyjnego, Wydawnictwo C.H. Beck, Warszawa, pp. 63-72.

Gad J. (2011), Rachunkowość w procesie nadzoru w spótkach publicznych, Wydawnictwo Uniwersytetu Łódzkiego, Łódź.

Gad J. (2012), Mechanizm wewnętrzny nadzoru korporacyjnego a system rachunkowości $w$ polskich spółkach publicznychnowe regulacje oraz wyniki badań, Zeszyty Naukowe Uniwersytetu Szczecińskiego. Finanse, Rynki Finansowe, Ubezpieczenia, no. 51, pp. 777-788.

Jensen M.C., Meckling W.H. (1976), Theory of the firm: Managerial behavior, agency costs and ownership structure, Journal of Financial Economics, vol. 3, no. 4, October, 308.

Jeżak J. (2010), Ład korporacyjny. Doświadczenia światowe oraz kierunki rozwoju, Wydawnictwo C.H. Beck, Warszawa.

Jeżak J. (2013), Corporate governance jako nowy obszar wiedzy i praktyki biznesowej, Studia Ekonomiczne. Zeszyty Naukowe Uniwersytetu Ekonomicznego w Katowicach, no. 141.

Konieczna I. (2015), Model biznesowy spótdzielni a model biznesowy przedsiębiorstw o innej formie organizacyjno-prawnej. Różnice, odrębność czynników sukcesu, Difin SA, Warszawa. 
Kyaitha R.S., Nzioki P.M., Corporate governance practices and financial performance of housing cooperatives in Kenya, European Journal of Economic and Financial Research, September 2017, source: https:/www.oapub.org/soc/index.php/ EJEFR/article/view/185/545 (data accessed: $19^{\text {th }}$ February 2020).

Masny M. (2002), Zarządzanie ryzykiem jako wymóg corporate governance, Przegląd Prawa Handlowego, no. 9(120).

Ministerstwo Skarbu Państwa (2004), Zasady nadzoru korporacyjnego OECD, Warszawa.

Stownik języka polskiego. Pobrane z: https://sjp.pl/korporacja.

Stownik poprawnej polszczyzny. Pobrane z: https://dobryslownik. pl/slowo/korporacja/22882/.

Szczypiór M. (2016), Rachunkowość i podatki spółdzielni mieszkaniowych. Przeglad orzecznictwa sadowego wraz z wytycznymi Ministerstwa Finansów, stan prawny na 1 kwietnia $2016 r$., Presshouse, Wrocław.

Ustawa z dnia 15 grudnia 2000 r. o spółdzielniach mieszkaniowych (Dz. U. 2001, nr 4, poz. 27 z późn. zm.).

Walczak W. (2011A), Funkcjonowanie rad nadzorczych w spótdzielniach mieszkaniowych, Przegląd Corporate Governance, nr 3, Polski Instytut Dyrektorów, Warszawa.
Walczak W. (2011B), Wspótpraca rady nadzorczej i zarząu w spótdzielni mieszkaniowej - studium przypadku, Przegląd Corporate Governance, no. 3.

Walczak W. (2012), Odwołanie członków zarząu spółdzielni mieszkaniowej - formalne procedury a praktyka, Przegląd Corporate Governance, nr 3.

Walczak W. (2013A), Failures of corporate governance in housing cooperatives - case study, Management and Business Administration. Central Europe, vol. 22, no. 3(122), Warszawa.

Walczak W. (2013B), Ztożoność relacji pomiędzy organami spótdzielni - teoria i praktyka, Przegląd Corporate Governance, nr 3 .

Walczak W. (2014), Wptyw ustawowych regulacji na standardy nadzoru korporacyjnego $w$ spółdzielniach mieszkaniowych, Organizacja i Zarządzanie, nr 2(26), Wydawnictwo Politechniki Śląskiej, Gliwice.

Zalega K. (2003), Systemy Corporate Governance a efektywność zarządzania spótka kapitałowa, SGH, Warszawa.

\section{MECHANIZMY NADZORU KORPORACYJNEGO W TEORII I PRAKTYCE SPÓŁDZIELNI MIESZKANIOWYCH}

Streszczenie: Celem badawczym jest przedstawienie wyników badań nad mechanizmami nadzoru korporacyjnego stosowanymi przez rady nadzorcze przy ocenie zarządzania działalnością polskich spółdzielni mieszkaniowych. Dla realizacji tego celu analizie poddana została istota nadzoru korporacyjnego, jego mechanizmów w odniesieniu do spółdzielni mieszkaniowych, a następnie zostały przeprowadzone badania empiryczne, których respondentami byli członkowie rady nadzorczej. Obiektem badań jest spółdzielnia mieszkaniowa działająca w Polsce. Osiągnięcie założeń celu artykułu możliwe było dzięki przeprowadzeniu pogłębionych studiów literatury krajowej i zagranicznej związanej z tematyką prac, a także metodzie ankietowej.

Słowa kluczowe: spółdzielnie mieszkaniowe, nadzór korporacyjny, rady nadzorcze, nadzór spółdzielczy, audyt. 